\title{
Statement on the Rapid Release of Genomic DNA Sequence
}

\author{
Notes from the meeting and statement compiled by Mark Guyer ${ }^{1}$
}

National Human Genome Research Institute, National Institutes of Health, Bethesda, Maryland 20892 USA

\begin{abstract}
A
the First (1996) and Second (1997) International Strategy Meetings on Human DNA Sequencing, the attendees discussed and strongly endorsed the concept that human genomic DNA sequence produced by large-scale DNA sequencing centers funded by the Human Genome Project should release data as rapidly as possible. In the case of unfinished data, it was suggested that sequence assemblies of 1-2 kb in size should be released within $24 \mathrm{hr}$ of generation. Finished data should be submitted to the public sequence databases on a similarly rapid time scale. Most of the funding agencies engaged in supporting the Human Genome Project have adopted policies that reflect the importance of rapid dissemination of genomic sequence data. Similarly the nucleotide sequence databases have made provision for the acceptance of the unfinished data as well as, of course, finished sequence data.

At the 1998 meeting, the question was raised about similar data dissemination practices for genomic sequence data from other organisms. The attendees unanimously agreed that this was also critical and adopted the following statement as individual scientists.

"As extensive determination of the genomic DNA sequence of several organ isms proceeds, it is increasingly clear that sequence information has enormous and immediate scientific value, even prior to its final assembly and completion. Delaying the release of either unfinished or finished genomic DNA sequence data serves no useful purpose and actually has the effect of slowing the progress of research. Therefore, the attendees at the Third International Strategy Meeting on Human Genome Sequencing (Bermuda, Feb. 27-28, 1998) agreed unanimously to support, as indi-
\end{abstract}

vidual scientists, the view that all publicly funded large-scale DNA sequencing projects, regardless of the organism, should deposit data immediately into the public domain, following the same guidelines that have previously been adopted by this group for human genomic sequence [see D.R. Bentley, Science 274: 533-534 (1996); http:// hugo.gdb.org/bermuda.htm]. The scientists attending this meeting will continue to adhere to these principles and urge all other scientists and policymaking groups involved in large-scale sequencing to adopt them as well."

This statement does not yet reflect, nor is it binding on, the policy of any funding agency. The attendees at the Third International Strategy Meeting on Human Genome Sequencing were Mark Adams, David Bentley, Bruce Birren, Martin Bobrow, Elbert Branscomb, Graham Cameron, Anthony V. Carrano, Ellson Chen, Francis Collins, David Cox, Mike Davies, Pieter de Jong, Richard Durbin, Glen Evans, Asao Fujiyama, Richard Gibbs, Eric Green, Phil Green, Mark Guyer, LaDeana Hillier, Ursula Hurten bach, Elke Jordan, Jill Kent, Fumihiko Kikuchi, Steven Koonin, Jane Lamerdin, Eric Lander, Chris Martin, Richard McCombie, John McPherson, Michael Morgan, Richard Myers, James Ostell, Ari Patrinos, Jane Peterson, Bruce Roe, Jane Rogers, Andre Rosenthal, Yoshiyuki Sakaki, Barbara Skene, Edwin Southern, Jilly Steward, John Sulston, Mark Vaudin, Jeffrey Wadsworth, Robert Waterson, James Watson, Jean Weissenbach, Richard Wilson, and MarieLaure Yaspo. 


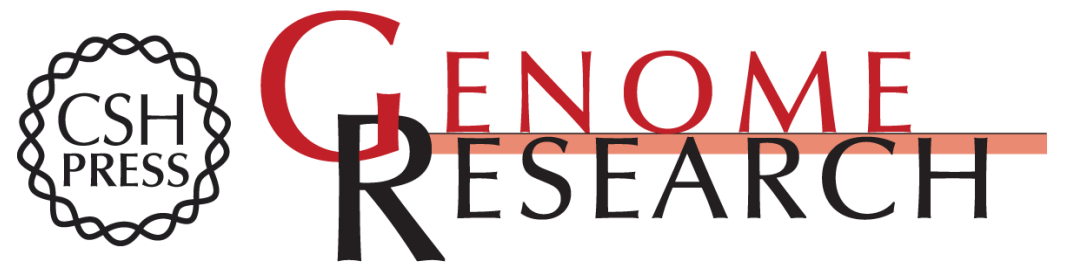

\section{Statement on the Rapid Release of Genomic DNA Sequence}

Notes from the meeting and statement compiled by Mark Guyer

Genome Res. 1998 8: 413

Access the most recent version at doi:10.1101/gr.8.5.413

\section{License}

Email Alerting Receive free email alerts when new articles cite this article - sign up in the box at the Service top right corner of the article or click here.

\section{Affordable, Accurate Sequencing.}

To subscribe to Genome Research go to: https://genome.cshlp.org/subscriptions 